\title{
THE ANALYSIS OF STUDENTS OPINION ABOUT THE TEACHERS SKILLS USING SUPERVISED LEARNING
}

\author{
Stefan-Gheorghe Pentiu ${ }^{1,2}$, ORCID ID: 0000-0002-5239-9493, \\ Laura-Bianca Bilius ${ }^{1,2 *}$, ORCID ID: 0000-0002-6081-3674 \\ ${ }^{1}$ Faculty of Electrical Engineering and Computer Science, Stefan cel Mare University of Suceava \\ ${ }^{2}$ MintViz Lab | MANSiD Research Center, Stefan cel Mare University of Suceava
}

*Corresponding author: Laura-Bianca Bilius, laura.bilius@usm.ro

Received: 11. 22. 2021

Accepted: 01. 30. 2022

\begin{abstract}
The system for biannual teachers' evaluation made by students, acquires a large amount of information that becomes difficult to be analyzed by a manager. It is true that delivers a final score, but it is calculated based only on the answers to the questions with several pre-defined answer options. In their questionnaire, there are also open questions in which students can express themselves freely. These answers contain valuable information, but an educational manager needs a long time to read them all individually. In this paper is proposed an automatic module for interpreting the answers. The module will report to the educational manager only the answers that need to be analyzed. The module uses natural language processing techniques, and supervised machine learning for selecting the answers to be analyzed in a certain context.
\end{abstract}

Keywords: degree of satisfaction, machine learning, supervised learning, natural language processing (NLP), sklearn.

Rezumat. Sistemul de evaluare semestrială a cadrelor didactice realizat de studenți dobândește o cantitate mare de informații, care devine greu de analizat de către un manager. Este adevărat, că oferă un punctaj final, dar se calculează doar pe baza răspunsurilor la întrebările cu mai multe opțiuni de răspuns predefinite. În chestionar există și întrebări deschise, în care elevii se pot exprima liber. Aceste răspunsuri conțin informații prețioase, dar un manager educațional are nevoie de mult timp pentru a le citi pe toate individual. În această lucrare este propus un modul automat de interpretare a răspunsurilor. Modulul va raporta managerului educațional doar răspunsurile care trebuie analizate. Modulul utilizează tehnici de procesare a limbajului natural și învăţarea automată supravegheată pentru selectarea răspunsurilor care urmează să fie analizate într-un anumit context.

Cuvinte cheie: grad de satisfacție, învățare automată, învăţare supravegheată, procesarea limbajului natural (NLP), sklearn.

\section{Introduction}

Monitoring the satisfaction of the beneficiaries of some services and products is a permanent concern of the management staff of any institution. With the rapid development of the industry, improving customer satisfaction has become an important task of a company [1]. 
This concern is also found in educational institutions at several levels, including universities. Within the "Stefan cel Mare" University of Suceava, the evaluation of teachers by students takes place twice a year. The students answer questionnaires that have questions with several answer options, but there are also two open-ended questions regarding the general impression that the teacher had and the suggestions for improving their activity. The result of this evaluation is expressed quantitatively based on the answers to the questions in which the students had to choose a certain answer option. The two open-ended questions are not considered when establishing the score, but each teacher reads and analyzes them carefully. Faculty and university managers must also analyze the results of staff evaluation by students.

The analysis is obviously based on quantitative results, but the educational manager is also interested in the free answers given by the students regarding the quality of the educational activity. But this task is difficult to accomplish due to a large number of evaluations (at the level of the Stefan cel Mare University of Suceava there are over 3000 evaluations every six months). A module for automatic analysis of students' free assessments, signaling, for example, negative evaluations for a teacher, would be very helpful. Then, the educational manager would analyze only the reported evaluations and will evaluate each one taking into account several aspects. Following this analysis, it will decide whether or not a discussion with the respective teacher is necessary in order to improve his / her activity. We emphasize that the role of the automatic text interpretation module is only to draw attention, not to make decisions. In the case of the inherent mistakes of current Al systems, the education manager will ignore the reported evaluation (for example as negative), but in the case of a low error rate, it is obvious that it will have much fewer evaluations to analyze.

The module for interpreting students' answers to questions without variants of predefined answers uses models based on natural language processing (NLP) and supervised learning for text analysis. In this first approach, we used algorithms where any word is very important for establishing the meaning of a text [2]. The answer given by a student is preprocessed in order to extract quantitative features and to represent the answers in a common feature space. Based on this representation, attempts are made to train models capable of extracting valuable information from text [2]. Specifically, we used k-NN, Multinomial Naïve Bayes, Logistic Regression, Support Vector Machine, Linear Discriminant Analysis, Random Forest, Multi-layer Perceptron, and Decision Tree classifiers to predict student opinions, positive or negative from an answer formulated in natural language. Model training takes place based on a training set, consisting of several answers given by students to assess the ability of teachers to explain various topics during class. For each answer, its meaning, positive or negative, was established by a human analyst and was indicated also in the training set.

The main issue of the module is to associate to a certain answer, a certain discrete meaning: positive, negative, or neutral. In machine learning, there are classification algorithms that may be trained to predict an associated discrete class [3] to the newly samples. In this paper, we studied the degree of satisfaction regarding the quality of educational activities performed by teachers using natural language processing techniques and supervised learning algorithms. We explored the performances in text processing of kNN, Multinomial Naïve Bayes, Logistic Regression, Support Vector Machine, Linear Discriminant Analysis, Random Forest, Multi-layer Perceptron, and Decision Tree classifiers. The analysis is based on the free answers given by the students where they evaluate the teachers' ability to explain various subjects during classes. 


\section{Related work}

Lessmann et al. [4] focused on customer relationship management by discussing the possibility to use supervised learning algorithms such as neural networks, support vector machines, random forest, or linear models. For example, Faisal et al. [5] studied customer satisfaction regarding the services provided by a company using the KNN algorithm. The accuracy obtained was $98 \%$ accuracy, and the input data consisted of single-answer multiplechoice questions and a 1 -6 rating scale. Xie et al. [1] studied the satisfaction degree of customers using a decision tree model that generated understandable results with a small computation cost. Zhou et al. [6] proposed an algorithm to analyze the online reviews of products. The model extracts even the sentiment intensity and is based on a fastText technique, latent Dirichlet allocation, and the Kano model. Tsami et al. [7] approached a tree classifier with the use of the algorithm C4.5 to study the satisfaction level of urban transport interchanges that provided highly accurate predictions; approximately $90 \%$. Baydogan et al. [8] also studied the customers' satisfaction on products or services using NLP methods and machine learning algorithms such as Naïve Bayes, J48, Decision Table, 3NN, 5NN, Multiclass Classification, and SMO but the last two gave the best results. Singh et al. [9] studied the overall degree of satisfaction using the random forest supervised learning algorithm that gave an approximately $75 \%$ accuracy.

In the following sections, we will describe a method of studying the human language using NLP and supervised learning algorithms in order to identify the satisfaction degree of people, building a demo application.

\section{Methodology}

One of the main goals of NLP libraries is to simplify text preprocessing [10]. Although there are many NLP Python libraries that are designed for various applications, such as NLTK, TextBlob, CoreNLP, Gensim, spaCy, polyglot, Pattern, in this paper we used the Scikit-learn library [11]. To preprocess the data, we used CountVectorizer() method from Scikit-learn library [11]. By definition, the method converts a text into a vector that contains the frequency of each word that occurs in the text. This process of feature extraction is called tokenization or encoding [12]. In Table 1 is the Python code for tokenization after which it is obtained the training and testing data [12].

Table 1

Tokenization of testing and learning data set

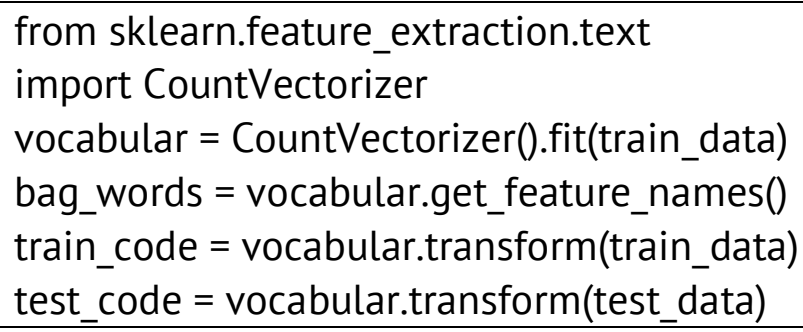

More exactly, the method generates an array, vocabular that contains all the unique words from the entire data set. Each answer from the data set is converted in an array, ${ }^{*}$ code, having the same size as vocabular where each value from * ${ }^{*}$ code[i] represents the frequency of the word from vocabular[i], as exemplified in [13].

In the classification stage, we used the tokenized data as input data for various supervised algorithms from the Scikit-learn library such as [11]: 
- KNN algorithm determines the $\mathrm{k}$ nearest neighbors of an entry $\mathrm{q}$ using various distance metrics such in [14], and a variety of ways to vote the class [15].

- Multinomial Naïve Bayes is a probabilistic method that assumes that the features are generated from a multinomial distribution [16].

- Support Vector Machine [17] is a non-probabilistic search for a separation surface between classes with a maximum margin [18].

- Linear Discriminant Analysis searches a linear combination of features to separate two or more classes expected to be normally distributed [19].

- Decision Tree is an algorithm that generates a classification model by constructing a decision tree [20] using different features and decision rules at different stages of classification [21].

- Random Forest is based on an ensemble tree and each tree depends on a random variable collection, and binary recursive partition [22].

- Multi-Layer Perceptron belongs to the neural network's family. In the case of MLP, the information travels in one direction, more exactly from the input nodes to the output nodes [23].

- Logistic Regression is a linear classification model based on computing the probabilities to classify a sample in each class [11, 24].

\section{Results}

In this study, we aimed to predict the degree of satisfaction of students who answer the question "What do you think is the defining personality trait for the teacher's teaching style?". In the demo application, we constructed the learning set with the answers classified in 2 classes, positive and negative opinions of the student about the teaching style; the data set was in Romanian, and in Annex 1 you will find its translation in English.

The learning set consists of free answers and numerical values, 1 for positive opinion and 0 for negative opinion (see Table 2). Trained on this learning set, a classifier will be able to analyze new opinions and recognizing them (see Table 3).

Table 2

\section{Learning data set}

\begin{tabular}{clcclc}
\hline Nr. & \multicolumn{1}{c}{ Answer } & Class & Nr. & \multicolumn{1}{c}{ Answer } & Class \\
\hline 1 & Un foarte bun profesor. & 1 & 7 & $\begin{array}{l}\text { Cursurile au prea mult } \\
\text { continut }\end{array}$ & 0 \\
2 & E interesat de ce preda & 1 & 8 & Cursurile nu sunt interactive & 0 \\
3 & $\begin{array}{l}\text { E interesat ca studentul sa } \\
\text { inteleaga }\end{array}$ & 1 & 9 & Explica foarte putin & 0 \\
4 & $\begin{array}{l}\text { Cursurile sunt foarte } \\
\text { interactive }\end{array}$ & 1 & 10 & Asteapta pauza ca sa plece & 0 \\
5 & Explica mult & 11 & 12 & $\begin{array}{l}\text { Cursurile sunt plicticoase. } \\
\text { inteleaga }\end{array}$ & 0 \\
6 & Explica foarte bine. & & & & 0 \\
\hline
\end{tabular}

Table 3

Testing data set

\begin{tabular}{clcclc}
\hline Nr. & \multicolumn{1}{c}{ Answer } & Class & Nr. & \multicolumn{1}{c}{ Answer } & Class \\
\hline 1 & Un profesor bun, bun & 1 & 4 & Explica putin si nu inteleg. & 0 \\
2 & Prietenos, bun ascultator & 1 & 5 & Cursurile nu sunt interesante & 0 \\
3 & Cursurile sunt foarte interactive & 1 & 6 & $\begin{array}{l}\text { Nu explica bine cursurile } \\
\text { teoretice }\end{array}$ & 0 \\
\hline
\end{tabular}




\section{Features extraction}

Once the testing data set has been established, we built the bag of words (see Table 4), and with its help the text will be transformed into feature vectors; using CountVectorizer() method from Scikit-learn [11].

Table 4

\section{The bag of words of the demo application}

['asteapta', 'au', 'bine', 'bun', 'ca', 'ce', 'continut', 'cursurile', 'de', 'explica', 'foarte', 'inteleaga', 'interactive', 'interesat', 'mult', 'nu', 'pauza', 'plece', 'plicticoase', 'prea', 'preda', 'profesor', 'putin', 'sa', 'studentul', 'sunt', 'un']

In Table 5 is depicted an example of numerical encoding as a dense vector of a student opinion from the learning data set. Because the number of words may be very large, the vector is represented as a sparse vector.

Table 5

\section{An answer and its numerical encoding}

Input text:

Un foarte bun profesor.

dense vector coding:

$[0001000000100000000001000001$ ] sparse vector coding:

$(0,3) 1$

$(0,10) 1$

$(0,21) 1$

$(0,26) 1$

Using the bag of words, the testing data is encoded in the same way as learning data.

\section{Classification}

Once the testing and learning data are pre-processed, we used them as input data for supervised learning algorithms from Scikit-learn library such as [11]:

- kNN: euclidean distance, $\mathrm{k}$ nearest neighbors;

- Multinomial Naïve Bayes;

- Support Vector Machine: one-versus-one coding, and linear kernel;

- Linear Discriminant Analysis: singular value decomposition solver;

- Decision Tree: length (vocabular)-1 the maximal number of decision split;

- Random Forest: 100 trees in the forest, 2 maximum depth of the tree;

- Multi-layer Perceptron: (length of answers from training data, length of vocabulary) hidden layers, limited-memory BFGS solver;

- Logistic Regression limited-memory BFGS solver, one-versus-rest coding.

According to the results from Table 6, we obtained 100\% accuracy for Multi-layer Perceptron, Support Vector Machine, and Logistic Regression classifiers. The smallest accuracy value was obtained by Linear Discriminant Analysis; therefore we can say that this data set is not linearly separated. Slightly above the medium level of accuracy values was obtained by $1 \mathrm{NN}, \mathrm{MNB}$, and RF, which are possible candidates for this data set. We can assume that if the bag of words is higher than these classifiers can get higher accuracy values.

Table 6

\section{Comparison of used algorithms}

\begin{tabular}{lr}
\hline Classifier & Accuracy \\
\hline 1NN & $83.33 \%$ \\
3NN & $50.00 \%$ \\
Multinomial Naïve Bayes (MNB) & $83.33 \%$ \\
SVM & $100 \%$ \\
\hline
\end{tabular}




\begin{tabular}{lr} 
& Continuation Table 6 \\
\hline Linear Discriminant Analysis (LDA) & $33.33 \%$ \\
Decision Tree (DT) & $66.66 \%$ \\
Random Forest (RF) & $83.33 \%$ \\
MLP & $100 \%$ \\
Logistic Regression (LR) & $100 \%$ \\
\hline
\end{tabular}

\section{Conclusion}

The use of supervised learning algorithms allows the prediction of the degree of satisfaction of users that have opinions on different topics. Because the analysis of the degree of satisfaction can be automated through natural language processing techniques, decisions can be made on a significant amount of data in a short time. The study aimed to examine in a frame of a demo application the performance of supervised learning algorithms using the free answers of the students on the quality of the activities performed by their teachers. In this study, we used KNN, Multinomial Naïve Bayes, SVM, Linear Discriminant Analysis, Logistic Regression, Random Forest, Multi-layer Perceptron, and Decision Tree classifiers and for each model, we computed the accuracy value. According to the obtained results, for the data set used in this study, the most appropriate classifiers were MLP, LR, and SVM. Therefore, extending the training data set to a very large number of responses, classifiers that have obtained high accuracy values can be taken into account to predict the positive or negative opinions of the students about the quality of the activities performed by their teachers.

Acknowledgments. We acknowledge the financial support provided by the project "Center for knowledge transfer to enterprises in the field of ICT - CENTRIC", Contract no. 5 / AXA 1 / 1.2.3 / G / 2018, Subsidiary contract with MICS Software, no. 15.875 / 2021. According to the author's PhD Research, "Stefan cel Mare" University of Suceava, Romania. This paper work was presented at the International Conference on Electronics Communications and Computing, IC ECCO, 21-22 October, 2021, Chisinau, TUM.

\section{References}

1. Xie M., Zhao W. "The analysis of customers' satisfaction degree based on decision tree model", 2010 Int. Conf. on Fuzzy Systems and Knowledge Discovery, 2010, doi: 10.1109/FSKD.2010.5569280.

2. Verspoor, Karin \& Cohen, Kevin. (2013). “Natural Language Processing”. 10.1007/978-1-4419-9863-7_158.

3. Stephens D., \& Diesing M. (2014). "A comparison of supervised classification methods for the prediction of substrate type using multibeam acoustic and legacy grain-size data. PloS one", 9(4), e93950. https://doi.org/10.1371/journal.pone.0093950.

4. Lessmann Stefan \& Voss Stefan. (2008). "Supervised Classification for Decision Support in Customer Relationship Management”. 10.1007/978-3-8349-9777-7_14.

5. Faisal S., \& Faisal N. (2020). "Implementation of K-Nearest Neighbor Algorithm for Customer Satisfaction". Buana Information Technology and Computer Sciences (BIT and CS). 1. 27-32. 10.36805/bit-cs.v1i2.886.

6. Zhou Feng \& Ayoub Jackie \& Xu, Qianli \& Yang, X. Jessie. (2019). “A Machine Learning Approach to Customer Needs Analysis for Product Ecosystems. Journal of Mechanical Design”. 142. 1. 10.1115/1.4044435.

7. Tsami M., Adamos G. Giannis, Nathanail, E. Budiloviča, E. Budilovich, Jackiva, I. Yatskiv and M. Vissarion. "A Decision Tree Approach for Achieving High Customer Satisfaction at Urban Interchanges", Transport and Telecommunication Journal, vol.19, no.3, 2018, pp.194-202. https://doi.org/10.2478/ttj-2018-0016.

8. Baydogan C., and Alatas B. "Detection of Customer Satisfaction on Unbalanced and Multi-Class Data Using Machine Learning Algorithms", International Informatics and Software Engineering Conference, 2019, doi: 10.1109/UBMYK48245.2019.8965631.

9. Singh A.K. (2001). "Analysis of Customer Satisfaction Data:Analysis of Customer Satisfaction Data". Technometrics. 43. 493-494. 10.1198/tech.2001. p. 54. 
10. Analytic Steps, 2020, “Top 12 Natural Processing Languages (NLP) Libraries with Python", https://www.analyticssteps.com/blogs/top-10-natural-processing-languages-nlp-libraries-python.

11. Scikit-learn, "Machine Learning in Python", https://scikit-learn.org/

12. Educative, "CountVectorizer in Python", https://www.educative.io/edpresso/countvectorizer-in-python

13. Geeks for Geeks, "Using CountVectorizer to Extracting Features from Text", https://www.geeksforgeeks.org/

14. Zhang, Shichao; Li, Xuelong; Zong, Ming; Zhu, Xiaofeng; Cheng, Debo. (2017). "Learning k for kNN Classification". ACM Transactions on Intelligent Systems and Technology.. 10.1145/2990508.

15. Cunningham P.,\& Delany S. (2007). k-Nearest neighbour classifiers. Mult Classif Syst. 54. 10.1145/3459665.

16. Pintu Lohar, Koel Dutta Chowdhury, Haithem Afli, Mohammed Hasanuzzaman and Andy Way, "ADAPT at IJCNLP-2017 Task 4: A Multinomial Naive Bayes Classification Approach for Customer Feedback Analysis task", International Joint Conference on Natural Language Processing, Shared Tasks, 2017.

17. Kecman Vojislav. (2005). Support Vector Machines - An Introduction. 10.1007/10984697_1.

18. Awad M., \& Khanna R. (2015). Support Vector Machines for Classification. 10.1007/978-1-4302-5990-9_3.

19. Abdulhamit Subasi, Chapter 3 - Machine learning techniques, Editor(s): Abdulhamit Subasi, Practical Machine Learning for Data Analysis Using Python, Academic Press, 2020, Pages 91-202, https://doi.org/10.1016/B978-0-12-821379-7.00003-5.

20. Capozzoli A., Cerquitelli T., Piscitelli M.S. "Chapter 11 - Enhancing energy efficiency in buildings through innovative data analytics technologiesa", Editor(s): Ciprian Dobre, Fatos Xhafa, In Intelligent Data-Centric Systems, Pervasive Computing, Academic Press, 2016, Pages 353-389, ISBN 9780128036631, https://doi.org/10.1016/B978-0-12-803663-1.00011-5.

21. Cheng-Jin Du, Da-Wen Sun. "4 - Object Classification Methods", Editor(s): Da-Wen Sun, In Food Science and Technology, Computer Vision Technology for Food Quality Evaluation, Academic Press, 2008, Pages 81-107, ISBN 9780123736420, https://doi.org/10.1016/B978-012373642-0.50007-7.

22. Cutler Adele \& Cutler, David \& Stevens, John. (2011). "Random Forests". 10.1007/978-1-4419-9326-7_5.

23. Marius Popescu \& Balas Valentina \& Perescu-Popescu Liliana \& Mastorakis Nikos. (2009). "Multilayer perceptron and neural networks". WSEAS Transactions on Circuits and Systems. 8.

24. Sperandei Sandro. (2014). "Understanding logistic regression analysis". Biochemia medica. 24. 12-8. 10.11613/BM.2014.003.

Annex:

Annex 1

Translation from Romanian into English of the learning and testing data set

\begin{tabular}{|c|c|c|}
\hline & Romanian & English \\
\hline 1 & Un foarte bun profesor & A very good teacher \\
\hline 2 & E interesat de ce preda & He's interested in what he teaches \\
\hline 3 & $\begin{array}{l}\text { E interesat ca studentul sa } \\
\text { inteleaga }\end{array}$ & He is interested in the student understanding \\
\hline 4 & Cursurile sunt foarte interactive & The courses are very interactive \\
\hline 5 & Explica mult & Explain a lot \\
\hline 6 & Explica foarte bine & Explain very well \\
\hline 7 & Cursurile au prea mult continut & The courses have too much content \\
\hline 8 & Cursurile nu sunt interactive & The courses are not interactive \\
\hline 9 & Explica foarte putin & Explain very little \\
\hline 10 & Asteapta pauza ca sa plece & Wait for the break to leave \\
\hline 11 & Cursurile sunt plicticoase & The courses are boring \\
\hline 12 & $\begin{array}{l}\text { Nu asteapta ca studentul sa } \\
\text { inteleaga }\end{array}$ & Don't wait for the student to understand \\
\hline 13 & Un profesor bun, bun & A good, good teacher \\
\hline 14 & Prietenos, bun ascultator & Friendly, good listener \\
\hline 15 & Cursurile sunt foarte interactive & The courses are very interactive \\
\hline 16 & Explica putin si nu inteleg & Explain a little and I don't understand \\
\hline
\end{tabular}

